\title{
Primary Study on the Combination Mode of Design and Supervision in the Construction Project Consulting Service in China
}

\author{
Bo Yi \\ School of Law, Southeast University, Nanjing 210096, China \\ E-mail: lawyer_yibo@yahoo.com.cn \\ Wei Xu \\ School of Civil Engineering, Southeast University, Nanjing 210096, China \\ E-mail:steven82117@126.com
}

Received: March 11, 2011

Accepted: March 26, 2011

doi:10.5539/jpl.v4n2p61

\begin{abstract}
The construction project consulting service is very important to the project safety and the project lifecycle. In the delivering project systems not only the selection of the project delivering mode but also the arrangement of design and supervision should be taken account into. In China, it is not uncommon that the design service and the construction supervision service respectively are delivered different bodies. The combination of design and supervision could largely improve the efficiency and performance of construction project, which will be the development direction in the consulting service.
\end{abstract}

Keywords: Consulting Service, Design and Supervision, Combination Mode, Development Direction

\section{Introduction}

When the project sponsor or owner selects the project implementation mode and the contract type, he must analyze three questions, i.e. which party is responsible for the project financing? Which party is responsible for the design and construction? Which party is liable for the risk, especially the risk in the quality control and the cost evaluation (Bunni N, 2005, P.66-82)? Different combinations of design, construction, and financing will form different project delivery systems, such as building-transfer (BT), design-building (DB), design-building-financing (DBF), and design-purchasing-construction (EPC). Development of various contracting methods instead of general contracting has always been the emphasis for relative departments of government in recent twenty years, and the research focus in the academic cycle (Zhang, 2003, P.30-36 \& Donald K, 1996, P.199-204 \& Patricia Galloway, 2009, P.7-15). However, when the owner organizes the project, he still faces another problem, i.e. how to arrange the design work and the supervision work? Should he let the design work and the supervision work to one consulting company with corresponding qualification and capacity (i.e. the company can provide the combination service of design and supervision)? Or should he respectively deliver design service and construction supervision service? That latter approach is the common practice in construction consulting service which has been employed in China. However, the research and practice about the former are still deficient at present.

\section{New combination of the project consulting service contents}

In the development of construction project, feasibility studies, planning, design, procurement, construction, supervision, project commissioning, all stages could be interacted and should be tightly linked each other. The project consulting service could cover the whole project lifecycle. According to the "Outlines of the Development Plan of the Project Consulting Industry in 2010-2015" issued by the National Development and Reform Commission, the project consulting service mainly include planning and consulting, investment opportunity studies, feasibility studies, surveying and designing, agency of bid invitation, construction and equipment supervision, and project management.

The FIDIC (Fédération lnternationale Des lngénieurs Conseils) is the most authoritative consulting engineer organization in the world, and the standard forms issued by it always influence the development of consulting service. According to the definition of FIDIC, the consulting services include (1) counseling services, (2) pre-investment studies, (3) design, (4) preparation of documents, (5) supervision, (6) specialized design and design development, (7) project management, and (8) program manager (Bunni N, 2005, .66-82). The content of the consulting service defined by FIDIC is very similar with the service content in the "Outlines of the Development Plan of the Project Consulting Industry in 2010-2015" issued by the National Development and Reform 


\section{Commission of China.}

At present, owners in China widely use the DBB delivery system (design-bidding-building) to organize the implementation of construction project. Under the context design firms mainly provide for service of design and construction supervision companies mainly provide for project supervision service. The initial idea of establishing the construction supervision system is to cover the whole lifecycle of construction project from the opportunity studies to project commissioning. Hence because of the practice in project supervision, quality, schedule, and cost in the construction are mainly focused on Therefore, practically, the article 32 of the Building Law of China defined that the supervisor inspect the construction quality, the construction schedule, and the construction capitals of the construction company on behalf of the owner. The project supervision in the construction stage is called as the "construction supervision" in practice.

In practice, the separation of design and supervision would hinder the design firm and the supervision body to provide more effective project consulting service, and hinder the development of the project consulting industry. The British contracting expert, Dr. N. Bunni, pointed out that for traditional construction contract, conceptual design and detailed design, preparation of contractual document, and the supervision in the construction are main contents of consulting services for which the consulting engineer could provide. Design and supervision service should be simultaneously provided by one consulting engineer, because it is wrong to employ different professionals for these two kinds of service with close relationship. There are many causes, and one of the most important causes is to avoid the ambiguity between design work and other services (Bunni N, 2005, .66-82).

When owner selects the design service, supervision service should be taken into consideration at the same time. If one entity takes in charge of design and construction supervision, the project performance could be improved and nobody could escape the obligation, for example the discrepancy in contractual documentation when the dispute arises out. The integration of design and supervision service could guarantee the final quality, efficiency, and value of construction project and reduce the disputes between contractor and owner.

\section{Legal obligation and responsibility of the combination service of design and supervision}

\subsection{Obligation and responsibility of the design service}

When the owner entrusts the design company to design the project, he want to convert his ideas about the project into concrete and feasible schemes and drawings with the help of professional personal's knowledge, so the construction company could implement the construction according to the drawings. Generally, the content of the committed design includes the project planning, the project design, the initial design, and the construction drawing design. The legal obligation and responsibility of the design company and the design staffs about the design service are seen in Table 1.

\subsection{Obligation and responsibility of the supervision service}

In China, the supervision company is same with the design company, the cost consulting company, and the bidding agency company in the catalog of the project consulting industry, and they all provide professional services for owner. But the service of the supervision company is a kind of specifically professional service, i.e. the management service. In the Article 32 of the Construction Law of China, "project supervisor should supervise the construction quality, the construction scheme, the use of construction capital of the contractor according to laws, administrative regulations, relative technical standards, design documents, and the construction project contract, on behalf of the construction company". Concretely, the legal responsibility and obligation of the supervision company and the relative staffs are seen in Table 2.

\subsection{Combination of the design service and the supervision service}

In the international project contract model, the consulting engineer's common obligation is standardized by the generalized way, for example, the Client/Consultant Model Services Agreement of FDIC regulated that engineers should utilize their reasonable skills to work cautiously and diligently (Item 1 of Article 5 of the Client/Consultant Model Services Agreement of FDIC). In China, the project consulting enterprises and their employees should insist objective, just, scientific, and reliable consulting rules in the "Professional Ethics and Behavior Rules of Chinese Engineering Consulting Industry", and wholeheartedly serve for clients, and elaborately work for their legal rights and interests from beginning to end, when they accept the commission and provide technical services.

When owner respective commits the design service and the supervision service and the change induced by the design deficiency happens, according to the contract, the construction company should request the supervision company for technical checking, and hands over the changed drawings to the supervision company, and the supervision company hands over the changed drawings to the construction company, and confirms relative changed additional contract cost. In this situation, the treatment of relative changes will be a long-term contract program, and 
except for lacking in efficiency, the design company and the construction company may shuffle their own responsibility for the delaying or the reworking, and the blind area of the contract responsibility would occur. But when owner only commits the combination service of design and supervision, above changed program could be "interiorized" in the project consulting company partly, which could effectively enhance the efficiency of project construction. Furthermore, to accomplish the construction work more successfully, the project consulting company must strengthen the design management, reduce the design deficiencies, and more "cautiously and diligently" "work" to maintain owner's legal rights and interests.

\section{Legal characters of the combination contract of design and supervision}

\subsection{Respective legal characters}

The design contract belongs to the construction project contract (work-for-hire contract), and the supervision contract belongs to the commission contract. The construction project contract and the commission contract are the contract to provide service (personal service). The construction project contract mainly means the payment obligation that the contractor accomplishes the project construction, and it emphasizes the contractor should accomplish certain works (Article 251 in Contract Law of China), and the commission contract mainly means the payment obligation that the trustee deals with affairs for the client (Article 360 in Contract Law of China). When owner commits the combination service of design and supervision to the single company with corresponding qualification and capacity, whether the contract belongs to the simultaneous contract or the mixed contract is still disputed in the academic cycle at present (the simultaneous contract means the parties sign couple contracts on same one legal document at the same time because of occasional factors, or the parties sign couple contracts which are linked or conditional each other, so it is different with the mixed contract. The mixed contract means the single one contract contains couple factors in different representative civil contracts. In short, the biggest difference between the mixed contract and the simultaneous contract is that the mixed contract is the single contract, and the simultaneous contract is the plural contract) (Shi, 1990). To make clear the difference of legal character of the contracts would help to distinguish parties' rights and obligations.

\subsection{Difference analysis of the design contract and the supervision contract}

The legal differences between the design contract and the supervision contract are mainly embodied in following aspects.

(1) For the specificity of the labor service, the design contract has not the specificity of the labor service, and when the owner permits, the designer can commits part of design work to the third party (sub-hire-of-work), but the consignee in the supervision contract must deal with the committed affairs by himself.

(2) For the imputation way of the liability for breach of contract, the designer should bear the liability for defects, which is the liability without fault, and the consignee in the supervision contract bear the obligation of reporting, duty of care, and good and hones management, which belongs to the liability for fault.

(3) For the terminal of contract, the customer in the design contract can terminate the contract at any time before the work is accomplished, and the any party in the commission contract can terminate the contract at any time.

(4) For the bearing of the liability for breach of contract, when the degree that the parties perform the contract doesn't achieve anticipated effect, the customer in the design contract can ask for repairing, remaking, reducing salary, and compensating for loss, and the consignee in the supervision contract should bear the liability for damage because of his faults or exceeding his authority.

(5) For the extent of damage liability, the designer's extent of damage liability in the design contract is not limited, and the consignee in the supervision contract only bear the limited damage liability in general condition.

At present, in existing project contract model texts in China, there are only the project design contract model and the commission supervision contract model, such as "Construction Project Design Contract (One) (Model Text) (GF-2000-0209)”, “Construction Project Design Contract (One) (Model Text) (GF-2000-0210)”, and "Construction Project Commission Supervision Contract (Model Text)", and there is not the combination contract model of design and supervision used for reference. Therefore, when owner or lawyer drafts the combination contract of design and supervision, he should pay more attention to the difference of legal character in these two different contract, especially in the rights of terminating contract and the extent of damage liability.

\section{Service gains of the combination service of design and supervision}

\subsection{Components of the service gains}

According to the project investment components and the "Regulations on Financial Management of Basic Construction (Ministry of Finance: [2002] No. 394)”, both the design service charge and the supervision service 
charge belong to the component in the other charges of project construction and the amortized investment, and the supervision service charge is paid from the construction management charge. The consignee in the combination contract of design and supervision provides two kinds of service including designing and supervising, and his salary should include the design service charge and the supervision service charge, i.e.

Service gains $=$ Design service charge + Supervision service charge

According to the New Edition Engineering Surveying and Designing Charging Standard (Ministry of Construction: [2002] No. 10), and the charge of designing service is the price fixed by the government, which can be fixed according to relative regulations of "Engineering Design Charging Standard", and according to the "Regulation on the Charging Administration about Construction Project Supervision and Relative Services (National Development and Reform Commission: [2002] No. 670)", the supervision service charge is fixed combining with the government fixed price and the market price adjustment, and it can be confirmed according to relative regulations in the "Regulation on the Charging Administration about Construction Project Supervision and Relative Services".

\subsection{Items of the service gains}

According to the "Regulations on Financial Management of Basic Construction", the "Accounting System of the State Construction Units (Ministry of Finance: [1995] No. 45)”, and relative regulations, in the whole project investment, though the design charge and the supervision charge all belong to the amortized investment, the amortized bases of these two kinds of investment are different when checking the newly increased asset value in the final settlement. The construction project investment is the amortized base of the design charge, and the sum of the construction and installment project investment and the required installment equipment investment is the amortized base of the supervision service charge. Therefore, to link the final settlement and exactly check the newly increased asset value, the design charge and the supervision charge should be respectively listed in the contract.

\subsection{Inquisition of liability for breach of contract}

In these two different contract relationships, designer and consignee's extents of liquidated damage liability are different. In the existing Article 26 of Construction Project Commission Supervision Contract (Model Text), "if consignor's economic loss is induced by supervisor's fault, the consignee should bear the compensation liability, and the accumulated compensation sum (except the supervisor colludes with the contractor) should not exceed the supervisor's gains (except for taxes)". About the limit of liability in the general article No. 4.4 in the "Highway Project Supervision Bid Document Model Text”, “supervisor's accumulated compensation is $30 \%$ of the supervision service charge, and when this limitation is achieved, the project employer has the right to terminate the supervision contract unilaterally, and confiscate supervisor's performance bond”. For designer, his extent of damage liability is not limited.

Therefore, when the consignee in the combination contract of design and supervision breaches the contract, the attribute of breaching contract should be made clear to confirm the extent of liability of liquidated damages, which is another cause to respectively establish the charge items for the design service charge and the supervision service charge.

\section{Conclusions}

The combination of design and supervision could effectively reduce the blind area of the contract interface and the contract responsibility, enhance the efficiency of project construction, and realize the owner's project target. The innovation and development of the project consulting service all request that the design company and the supervision company with capacity could provide better combination service of design and supervision in more wider range. Furthermore, because there are many different regulations about the design companies and their engineers, the supervision companies and their engineers, the design contract and the design service charge, the supervision contract and the supervision service charges in relative laws and the basic financial management systems, to make clear these laws and regulations could largely help the development of the combination service of design and supervision.

\section{References}

Bunni N. (2005). The FIDIC Forms of Contract (Third Edition). USA: Blackwell Publishing Ltd. P.66-82.

Donald K. Stager. (1996). Organizing and Managing A Finance-Design- Build Project in Turkey: Fourth Roebling Lecture, 1995a. Journal of Construction project and Management. No.9. P.199-204.

Patricia Galloway. (2009). Design-Build/EPC Contractor's Heightened Risk-Changes in a Changing World. Journal of Legal Affairs and Dispute Resolution in Engineering and Construction. No.1(1). P.7-15.

Shi, Shangkuan. (1990). General Introduction of Obligation Law. Taipei: Angle Publishing Co. Ltd. 
Zhang, Shuibo \& He, Bosen. (2003). International Cutting-edge Research on the Design-build Delivery Systems. China Civil Engineering Journal. No.36(3). P.30-36.

Table 1. Legal obligation and responsibility of design company and design engineers

\begin{tabular}{|c|c|c|}
\hline \multirow{7}{*}{$\begin{array}{l}\text { About } \\
\text { design } \\
\text { company }\end{array}$} & Obligation & Responsibility \\
\hline & $\begin{array}{l}\text { Qualification administration: } \\
\text { Article } 13 \text { and } 26 \text { in Construction Law } \\
\text { Article } 8 \text { in Regulations on Administration } \\
\text { of Surveying and Designing of Construction } \\
\text { Projects } \\
\text { Article } 18 \text { in Regulations on Administration } \\
\text { of the Quality of Construction Projects }\end{array}$ & $\begin{array}{l}\text { Administrative responsibility: Imposed fine penalties, and can be ordered to stop } \\
\text { business operations for rectification, with its qualification level reduced. An } \\
\text { organization found to have serious violations shall be revoked business license, with } \\
\text { all its illegal incomes confiscated. (Article } 35 \text { in Regulations on Administration of } \\
\text { Surveying and Designing of Construction Projects). }\end{array}$ \\
\hline & $\begin{array}{l}\text { Prohibition of subcontracting: } \\
\text { Article } 28 \text { in Construction Law of China } \\
\text { Article } 20 \text { in Regulations on Administration } \\
\text { of Surveying and Designing of Construction } \\
\text { Projects }\end{array}$ & $\begin{array}{l}\text { Administrative responsibility: Imposed fine penalties, and can be ordered to stop } \\
\text { business operations for rectification, with its qualification level reduced. An } \\
\text { organization found to have serious violations shall be revoked business license. } \\
\text { (Article } 39 \text { in Regulations on Administration of Surveying and Designing of } \\
\text { Construction Projects). }\end{array}$ \\
\hline & $\begin{array}{l}\text { Illegal subcontracting: } \\
\text { Article } 29 \text { in Construction Law of China } \\
\text { Article } 19 \text { in Regulations on Administration } \\
\text { of Surveying and Designing of Construction } \\
\text { Projects }\end{array}$ & $\begin{array}{l}\text { Administrative responsibility: Imposed fine penalties, and can be ordered to stop } \\
\text { business operations for rectification, with its qualification level reduced. An } \\
\text { organization found to have serious violations shall be revoked business license. } \\
\text { (Article } 62 \text { in Regulations on Administration of the Quality of Construction } \\
\text { Projects). }\end{array}$ \\
\hline & $\begin{array}{l}\text { Design obligation: } \\
\text { Article } 56 \text { and } 57 \text { in Construction Law of } \\
\text { China } \\
\text { Article } 40 \text { in Regulations on Administration } \\
\text { of Surveying and Designing of Construction } \\
\text { Projects } \\
\text { Article } 21 \text { in Regulations on Administration } \\
\text { of the Quality of Construction Projects }\end{array}$ & $\begin{array}{l}\text { Administrative responsibility: Imposed fine penalties, and an organization found } \\
\text { to induce great engineering qualitative accident can be ordered to stop business } \\
\text { operations for rectification, with its qualification level reduced. An organization } \\
\text { found to have serious violations shall be revoked business license. } \\
\text { Civil responsibility: An organization found to induce losses shall bear the liability } \\
\text { for damage. (Article } 63 \text { in Regulations on Administration of the Quality of } \\
\text { Construction Projects and Article } 56 \text { in Regulations on Safe Production and } \\
\text { Administration of Construction Projects). }\end{array}$ \\
\hline & $\begin{array}{l}\text { Agency obligation: } \\
\text { Article } 23 \text { in Regulations on Administration } \\
\text { of the Quality of Construction Projects } \\
\end{array}$ & bility \\
\hline & $\begin{array}{l}\text { Committing the third party to work: } \\
\text { Article } 297 \text { in Contract Law }\end{array}$ & Joint responsibility \\
\hline \multirow{3}{*}{$\begin{array}{l}\text { About } \\
\text { design } \\
\text { engineers }\end{array}$} & $\begin{array}{l}\text { Personal certification: } \\
\text { Article } 14 \text { in Construction Law of China } \\
\text { Article } 10 \text { in Regulations on Administration } \\
\text { of Surveying and Designing of Construction } \\
\text { Projects }\end{array}$ & $\begin{array}{l}\text { Administrative responsibility: Can be ordered to stop business operations for } \\
\text { rectification, or be revoked business license. } \\
\text { Civil responsibility: An organization found to induce losses shall bear the liability } \\
\text { for damage. (Article } 37 \text { in Regulations on Administration of Surveying and } \\
\text { Designing of Construction Projects). }\end{array}$ \\
\hline & $\begin{array}{l}\text { Design responsibility person's obligation: } \\
\text { Article } 56 \text { in Regulations on Safe Production } \\
\text { and Administration of Construction Projects }\end{array}$ & $\begin{array}{l}\text { Criminal responsibility: Give criminal sanctions for the directly responsible person } \\
\text { according to relative rules in the Criminal Law. (Article } 56 \text { in Regulations on Safe } \\
\text { Production and Administration of Construction Projects). }\end{array}$ \\
\hline & $\begin{array}{l}\text { Design obligation according to compulsory } \\
\text { standard: } \\
\text { Article } 19 \text { in Regulations on Administration } \\
\text { of the Quality of Construction Projects } \\
\text { Article } 13 \text { in Regulations on Safe Production } \\
\text { and Administration of Construction Projects }\end{array}$ & $\begin{array}{l}\text { Administrative responsibility: Can be ordered to stop business operations. An } \\
\text { organization found to have serious violations shall be revoked business license and } \\
\text { refused for registration (Article } 39 \text { in Regulations on Administration of the Quality } \\
\text { of Construction Projects). } \\
\text { Criminal responsibility: Give criminal sanctions for the directly responsible person } \\
\text { according to relative rules in the Criminal Law when committing the criminal law. } \\
\text { (Article } 58 \text { in Regulations on Safe Production and Administration of Construction } \\
\text { Projects). }\end{array}$ \\
\hline
\end{tabular}


Table 2. Legal obligation and responsibility of supervision company and supervision engineers

\begin{tabular}{|c|c|c|}
\hline \multirow{7}{*}{$\begin{array}{l}\text { About } \\
\text { supervision } \\
\text { company }\end{array}$} & Obligation & Responsibility \\
\hline & $\begin{array}{l}\text { Qualification administration: } \\
\text { Article } 31 \text { in Construction Law } \\
\text { Article } 34 \text { in Regulations on } \\
\text { Administration of the Quality } \\
\text { of Construction Projects }\end{array}$ & $\begin{array}{l}\text { Administrative responsibility: Imposed fine penalties, and can be ordered to stop business } \\
\text { operations for rectification, with its qualification level reduced. An organization found to } \\
\text { have serious violations shall be revoked business license, with all its illegal incomes } \\
\text { confiscated. (Article } 60 \text { in Regulations on Administration of the Quality of Construction } \\
\text { Projects). }\end{array}$ \\
\hline & $\begin{array}{l}\text { Specificity of supervision } \\
\text { service: } \\
\text { Article } 34 \text { in Construction Law } \\
\text { Article } 34 \text { in Regulations on } \\
\text { Administration of the Quality } \\
\text { of Construction Projects }\end{array}$ & $\begin{array}{l}\text { Administrative responsibility: Imposed fine penalties, and can be ordered to stop business } \\
\text { operations for rectification, with its qualification level reduced. An organization found to } \\
\text { have serious violations shall be revoked business license, with all its illegal incomes } \\
\text { confiscated. (Article } 62 \text { in Regulations on Administration of the Quality of Construction } \\
\text { Projects). }\end{array}$ \\
\hline & $\begin{array}{l}\text { Independence of supervision } \\
\text { service: } \\
\text { Article } 34 \text { in Construction Law } \\
\text { Article } 35 \text { in Regulations on } \\
\text { Administration of the Quality } \\
\text { of Construction Projects }\end{array}$ & $\begin{array}{l}\text { Administrative responsibility: Imposed fine penalties, with all its illegal incomes } \\
\text { confiscated, reduce its qualification level or revoke its business license. (Article } 68 \text { in } \\
\text { Regulations on Administration of the Quality of Construction Projects). }\end{array}$ \\
\hline & $\begin{array}{l}\text { Forbidden behaviors: } \\
\text { Article } 35 \text { in Construction Law } \\
\text { Article } 67 \text { in Regulations on } \\
\text { Administration of the Quality } \\
\text { of Construction Projects }\end{array}$ & $\begin{array}{l}\text { Administrative responsibility: Imposed fine penalties, be ordered to rectify its mistakes, } \\
\text { with all its illegal incomes confiscated, reduce its qualification level or revoke its business } \\
\text { license. } \\
\text { Joint responsibility (Article } 67 \text { in Regulations on Administration of the Quality of } \\
\text { Construction Projects). }\end{array}$ \\
\hline & $\begin{array}{l}\text { Report obligation: } \\
\text { Article } 32 \text { in Construction Law } \\
\text { Article } 57 \text { in Regulations on } \\
\text { Safe Production and } \\
\text { Administration of Construction } \\
\text { Projects }\end{array}$ & $\begin{array}{l}\text { Administrative responsibility: Imposed fine penalties, and can be ordered to stop business } \\
\text { operations for rectification, with its qualification level reduced. An organization found to } \\
\text { have serious violations shall be revoked business license. (Article } 57 \text { in Regulations on Safe } \\
\text { Production and Administration of Construction Projects). }\end{array}$ \\
\hline & $\begin{array}{l}\text { Quality and safety supervision } \\
\text { responsibility: } \\
\text { Article } 36 \text { in Regulations on } \\
\text { Administration of the Quality } \\
\text { of Construction Projects } \\
\text { Article } 57 \text { in Regulations on } \\
\text { Safe Production and } \\
\text { Administration of Construction } \\
\text { Projects }\end{array}$ & $\begin{array}{l}\text { Administrative responsibility: Imposed fine penalties, and can be ordered to stop business } \\
\text { operations for rectification, with its qualification level reduced. An organization found to } \\
\text { have serious violations shall be revoked business license. (Article } 57 \text { in Regulations on Safe } \\
\text { Production and Administration of Construction Projects). }\end{array}$ \\
\hline \multirow[b]{2}{*}{$\begin{array}{l}\text { About } \\
\text { engineers }\end{array}$} & $\begin{array}{l}\text { Personal qualification: } \\
\text { Article } 14 \text { in Construction Law } \\
\text { Article } 31 \text { in Regulations on } \\
\text { Administration for Registered } \\
\text { Supervision Engineers }\end{array}$ & $\begin{array}{l}\text { Administrative responsibility: Confiscate illegal incomes, and imposed fine penalties } \\
\text { Civil responsibility: An organization found to induce losses shall bear the liability for } \\
\text { damage } \\
\text { Criminal responsibility: Give criminal sanctions for the directly responsible person } \\
\text { according to relative rules in the Criminal Law when committing the criminal law. (Article } \\
58 \text { in Regulations on Administration for Registered Supervision Engineers). }\end{array}$ \\
\hline & $\begin{array}{l}\text { Supervision } \\
\text { according to compulsory } \\
\text { standard: } \\
\text { Article } 38 \text { in Regulations on } \\
\text { Administration of the Quality } \\
\text { of Construction Projects } \\
\text { Article } 14 \text { in Regulations on } \\
\text { Safe Production and } \\
\text { Administration of Construction } \\
\text { Projects }\end{array}$ & $\begin{array}{l}\text { Administrative responsibility: Be ordered to stop business operations, and an organization } \\
\text { found to have serious violations shall be revoked business license, and refused for } \\
\text { registration (Article } 72 \text { in Regulations on Administration of the Quality of Construction } \\
\text { Projects). } \\
\text { Criminal responsibility: Give criminal sanctions for the directly responsible person } \\
\text { according to relative rules in the Criminal Law when committing the criminal law. (Article } \\
58 \text { in Regulations on Safe Production and Administration of Construction Projects). }\end{array}$ \\
\hline
\end{tabular}

